\title{
Xanthones and Coumarins from Kielmeyera lathrophyton
}

\author{
Frederico G. Cruz ${ }^{a *}$,José T. da Silva-Neto ${ }^{a}$ and Maria L. S. Guedes ${ }^{b}$ \\ anstituto de Química, Universidade Federal da Bahia, 40170-290, Salvador-BA, Brazil \\ ${ }^{\mathrm{b}}$ Instituto de Biologia, Universidade Federal da Bahia, 40170-290, Salvador-BA, Brazil
}

Do extrato hexânico de Kielmeyera lathrophyton foram isoladas duas novas xantonas, 1,5diidroxi-6'-metil-6' -(4-metil-3-pentenil)-pirano( $2^{\prime}, 3$ ':3,2)-xantona, 1,7-diidroxi-6' -metil-6'-(4metil-3-pentenil)-pirano(2',3':3,2)-xantona. Uma terceira xantona, a 2,3-metilenodioxixantona, teve a atribuição dos dados de $\mathrm{RMN}$ de ${ }^{13} \mathrm{C}$ revista. Foram isoladas ainda seis cumarinas sendo duas delas inéditas, 7-hidroxi-8-(3-metil-1-oxobutil)-4-s-butil-6', 6'-dimetilpirano(2',3':5,6)cumarina e 7-hidroxi-8-(2-metil-1-oxobutil)-4-s-butil-6',6'dimetilpirano(2',3':5,6)-cumarina. Além dessas substâncias foram isolados ainda o $\delta$-tocotrienol, a friedelina, o $24 \alpha$-etilcolest-5-en-3-ona e o $24 \alpha$-etilcolest-5,22-dien-3-ol. Estes compostos foram identificados através de suas propriedades espectroscópicas e por comparação de seus dados espectroscópicos com dados da literatura.

Three xanthones and six coumarins were isolated from the hexane extract of the stems of Kielmeyera lathrophyton, among them two new prenylated xanthones 1,5-dihydroxy-6'-methyl6'-(4-methyl-3-pentenyl)-pyrano(2',3':3,2)-xanthone, 1,7-dihydroxy-6'-methyl-6'-(4-methyl-3pentenyl)-pyrano $\left(2^{\prime}, 3^{\prime}: 3,2\right)$-xanthone, and two new 4-s-butylcoumarins 7-hydroxy-8-(3-methyl1-oxobutyl)-4-s-butyl-6',6'-dimethylpyrano (2',3':5,6)-coumarin, 7-hydroxy-8-(2-methyl-1oxobutyl)-4-s-butyl-6',6'-dimethylpyrano $\left(2^{\prime}, 3^{\prime}: 5,6\right)$-coumarin, along with the compounds, $\delta$-tocotrienol, friedelin, $24 \alpha$-ethylcholest-5-en-3-one, and , 24 $\alpha$-ethylcholest-5,22-dien-3-ol. These compounds were identified by comparison with literature data, and their spectroscopic properties.

Keywords: Kielmeyera lathrophyton, Guttiferae, xanthones, 4-alkylcoumarins, 4-phenylcoumarins, neoflavonoids

\section{Introduction}

Guttiferae is a family generally confined to the tropics. The genus Kielmeyera is endemic to South America ${ }^{1}$ with large occurrence in the Brazilian "cerrados" (savannas). Early studies with Kielmeyera species from "cerrado" of the Central Brazilian plateau showed xanthones as principal constituents $^{2-10}$. On the other hand, in our recent investigation with Kielmeyera species from "restinga" (sand dunes) of Bahia state coast we have found mainly prenylated 4-phenyl and 4- $n$-propylcoumarins ${ }^{11,12}$.

In the species $K$. lathrophyton, which was harvested on a "campo rupestre" area in the Chapada Diamantina, Bahia state, a region localized between the coast and the Central plateau, we found beyond xanthones 4-alkyl and 4-phenyl coumarins.

\section{Experimental}

UV: $\mathrm{CH}_{3} \mathrm{OH}$ and $\mathrm{CH}_{3} \mathrm{OH} / \mathrm{NaOH}$. EIMS: Direct probe insert at $70 \mathrm{eV}$. NMR: Gemini 300-Varian. 241 PerkinElmer polarimeter.

\section{Plant material}

Kielmeyera lathrophyton, Saady, was collected at Parque Nacional da Chapada Diamantina, Bahia, Brazil, in August 1996. A voucher specimen, No 35942, has been deposited in the Alexandre Leal Costa Herbarium, Instituto de Biologia, Universidade Federal da Bahia, Salvador, Brazil.

\section{Extraction and Isolation}

Dried stems $(5 \mathrm{~kg})$ were extracted with hexane. The extract $(80 \mathrm{~g})$ was concentrated under reduced pressure and then submitted to chromatography on silica gel column using hexane-EtOAc gradient. Some fractions were rechromatographed on silica gel $\mathrm{CC}$ using hexane-EtOAc gradient to give $1(0.031 \mathrm{~g}), 2(0.006 \mathrm{~g}), 3(0.008 \mathrm{~g})$, $4(0.092 \mathrm{~g}), \mathbf{5}(0.023 \mathrm{~g}), \mathbf{6}(0.035 \mathrm{~g}), 7$ (0.040 g), 9 (0.122 $\mathrm{g}), \mathbf{1 0}(0.017 \mathrm{~g})$, and a mixture of $\mathbf{8}(70 \%, 0.083 \mathrm{~g})$ and $\mathbf{3}$ $(30 \%, 0.036 \mathrm{~g})$.

Compound 1. $\mathrm{C}_{23} \mathrm{H}_{22} \mathrm{O}_{5}$, 1,5-dihydroxy-6'-methyl-6'-(4methyl-3-pentenyl)-pyrano(2',3':3,2)-xanthone. Yellow crystals, mp $142-143^{\circ} \mathrm{C}$ (hexane); ${ }^{1} \mathrm{H}$ and ${ }^{13} \mathrm{C}$ NMR, Table 1. 
EIMS $m / z 378[\mathrm{M}]^{+}(6 \%), 363$ (2), 295(100); $\lambda_{\text {max }} / \mathrm{nm}$ $(\mathrm{MeOH}) 238,268,294,312 ; v_{\max } / \mathrm{cm}^{-1} 3338,1652,1613$, 1581, 1497, (film $\left.\mathrm{CHCl}_{3}\right) ;[\alpha]^{22}{ }_{\mathrm{D}}+2.30\left(c 0.4, \mathrm{CHCl}_{3}\right)$.

Compound 2. $\mathrm{C}_{23} \mathrm{H}_{22} \mathrm{O}_{5}$, 1,7-dihydroxy-6'-methyl-6'(4-methyl-3-pentenyl)-pyrano(2',3':3,2)-xanthone. Yellow amorphous solid; ${ }^{1} \mathrm{H}$ and ${ }^{13} \mathrm{C}$ NMR, Table 1 ; EIMS $\mathrm{m} / \mathrm{z}$ $378[\mathrm{M}]^{+}(20 \%), 363(5), 295$ (100). $\lambda_{\max } / \mathrm{nm}\left(\mathrm{CH}_{3} \mathrm{OH}\right)$ 223, 253, 285; $v_{\max } / \mathrm{cm}^{-1} 3430,1652,1613,1467$, (film $\left.\mathrm{CHCl}_{3}\right) ;[\alpha]^{22}{ }_{\mathrm{D}}+5.76\left(c 0.6 \mathrm{CHCl}_{3}\right)$.

Compound 3. $\mathrm{C}_{14} \mathrm{H}_{8} \mathrm{O}_{4}$, 2,3-methylenedioxyxanthone. ${ }^{1} \mathrm{H}$ and ${ }^{13} \mathrm{C}$ NMR, Table 1; EIMS $m / z 240[\mathrm{M}]^{+}(100 \%)$, 241 (15), 239 (61),149 (8), 126 (13), 105 (9); UV $\lambda_{\text {max }}$ ' $\mathrm{nm}\left(\mathrm{CH}_{3} \mathrm{OH}\right) 225,240,270,304,350 ; v_{\text {max }} / \mathrm{cm}^{-1} 1655$, 1632, 1608, 1577, 1466, 935 (film $\mathrm{CHCl}_{3}$ ).

Compound 4. $\mathrm{C}_{23} \mathrm{H}_{28} \mathrm{O}_{5}$, 7-hydroxy-8-(3-methyl-1oxobutyl)-4-s-butyl-6',6'-dimethylpyrano(2',3':5,6)coumarin. Yellow-greenish amorphous solid; ${ }^{1} \mathrm{H}$ and ${ }^{13} \mathrm{C}$ NMR, Table 3; EIMS m/z 384 [M] $^{+}$(29\%), 369 (100), 341 (21), 327 (12), 313 (9); $[\alpha]^{22}{ }_{\mathrm{D}}+1.82\left(c \quad 0.4 \mathrm{CHCl}_{3}\right)$.

Compound 5. $\mathrm{C}_{23} \mathrm{H}_{28} \mathrm{O}_{5}$, 7-hydroxy-8-(2-methyl-1oxobutyl)-4-s-butyl-6',6'-dimethylpyrano(2',3':5,6)coumarin. Yellow-greenish amorphous solid; ${ }^{1} \mathrm{H}$ and ${ }^{13} \mathrm{C}$ NMR, Table 3; EIMS m/z $384\left[\mathrm{M}^{+}\right.$(38\%), 369 (100), 341 (14), 327 (49), 313 (6); $v_{\text {max }} / \mathrm{cm}^{-1} 3462,1740,1614$, 1580, 1557, 1383, 1197, 1143, (film $\left.\mathrm{CHCl}_{3}\right) ;[\alpha]_{\mathrm{D}}^{22}+0.69$ (c $0.5 \mathrm{CHCl}_{3}$ ).

Compound 6. $\mathrm{C}_{22} \mathrm{H}_{26} \mathrm{O}_{5}$, 7-hydroxy-8-(2-methyl-1oxobutyl)-4-n-propyl-6',6'-dimethylpyrano(2',3':5,6)coumarin. Yellow-greenish amorphous solid; ${ }^{1} \mathrm{H}$ NMR (300 $\mathrm{MHz}, \mathrm{CDCl}_{3}$ ) $\delta 0.97$ (t, 3H, $7.3 \mathrm{~Hz}, \mathrm{H}-4$ "), 1.04 (t, 3H, $7.3 \mathrm{~Hz}, \mathrm{H}-3$ "'), 1.24 (d, 3H, $6.7 \mathrm{~Hz}, \mathrm{H}-5$ "), 1.40 (m, 2H, H-3"), 1.52 (s, 6H, H-7' e H-8'), $\delta 1.60$ (m, 2H, H-2'”), 2.90 (t, 2H, 7.5 Hz; H-1'”), 3.89 (m, 1H, H-2”), 5.57 (d, $\left.1 \mathrm{H}, 10.0 \mathrm{~Hz}, \mathrm{H}-5^{\prime}\right), 6.72$ (d, 1H, $10.0 \mathrm{~Hz}, \mathrm{H}-4$ '), 6.00 (s, $1 \mathrm{H}, \mathrm{H}-3), 14.45$ (s, $1 \mathrm{H}, 7-\mathrm{OH}) ;{ }^{13} \mathrm{C} \mathrm{NMR}\left(75 \mathrm{MHz} \mathrm{CDCl}_{3}\right.$ ), $\delta 159.1(\mathrm{C}-2), 110.5$ (C-3), $158.3(\mathrm{C}-4), 102.7$ (C-4a), 157.1 (C-5), 106.1 (C-6), 163.1 (C-7), 104.1 (C-8), 156.5 (C8a), 116.0 (C-4'), 126.3 (C-5'), 79.6 (C-6'), 28.2 (C-7'), 28.2 (C-8'), 210.7 (C-1"), 46.9 (C-2"), 27.2 (C-3"), 11.7 (C-4"), 16.5 (C-5"), 39.0 (C-1"”), 23.3 (C-2"”), 13.9 (C3"'); EIMS m/z $370\left[\mathrm{M}^{+}\right.$(43\%), 355 (100), 337 (25), 313 (71); $v_{\text {max }} / \mathrm{cm}^{-1} 3466,1732,1557,1463,1386,1145$, (film $\left.\mathrm{CHCl}_{3}\right) ; \lambda_{\text {max }} / \mathrm{nm}\left(\mathrm{CH}_{3} \mathrm{OH}\right) 306 ; \lambda_{\text {max }} \mathrm{NaOH} / \mathrm{nm}$ $\left(\mathrm{CH}_{3} \mathrm{OH}\right) 384$.

Compound 7. $\mathrm{C}_{25} \mathrm{H}_{24} \mathrm{O}_{5}$, 5-hydroxy-6-(2-methyl-1oxobutyl)-4-phenyl-6',6'-dimethylpyrano(2',3':7,8)coumarin. Yellow-greenish amorphous solid; ${ }^{1} \mathrm{H}$ NMR (300 $\left.\mathrm{MHz}, \mathrm{CDCl}_{3}\right) \delta 0.90$ (t, 3H, $7.3 \mathrm{~Hz}, \mathrm{H}-4$ "), 1.16 (d, 3H, $6.6 \mathrm{~Hz}, \mathrm{H}-5$ ') 1.40 (m, 2H, H-3”), 1.57 (s, 6H, H-7' e H8'), 3.74 (m, 1H, H-2”), 5.64 (d, 1H, 10.0 Hz, H-5'), 5.99 (s, 1H, H-3), 6.90 (d, 1H, 10.0 Hz, H-4'), 7.31 (m, 1H, phenyl), 7.40 (m, 4H, phenyl), 14.69 (s, 1H, 5-OH). ${ }^{13} \mathrm{C}$ NMR (75 MHz, $\mathrm{CDCl}_{3}$ ), 159.5 (C-2), 112.5 (C-3), 154.6 (C-4), 102.1 (C-4a), 164.3 (C-5), 106.8 (C-6), 156.3 (C7), 101.4 (C-8), 157.7 (C-8a), 115.4 (C-4'), 126.2 (C-5'), 79.7 (C-6'), 28.0 (C-7'), 28.0 (C-8'), 211.3 (C-1”), 46.5 (C-2”), 26.5 (C-3"), 11.7 (C-4"), 16.5 (C-5"), 139.0 (C1 "'), 127.0 (C-2", and C-6"”), 127.5 (C-3"” and C-5"'), 128.1 (C-4"”). EIMS m/z 404 [M] $^{+}$(44\%), 389 (100), 347 (86); $v_{\text {max }} / \mathrm{cm}^{-1} 3448,1748,1650,1582,1132,1115,699$ (film $\left.\mathrm{CHCl}_{3}\right) ; \lambda_{\max } / \mathrm{nm}\left(\mathrm{CH}_{3} \mathrm{OH}\right) 232,285,345 ; \lambda_{\max } \mathrm{NaOH} /$ nm 250, 313, 433.

Compound 8. $\mathrm{C}_{25} \mathrm{H}_{24} \mathrm{O}_{5}$, 5-hydroxy-6-(3-methyl-1oxobutyl)-4-phenyl-6',6'-dimethylpyrano(2',3':7,8)coumarin. Yellow-greenish amorphous solid; ${ }^{1} \mathrm{H}$ NMR $(300$ $\left.\mathrm{MHz}, \mathrm{CDCl}_{3}\right) \delta 0.94$ (d, 6H, $6.7 \mathrm{~Hz}, \mathrm{H}-4$ "), 1.60 (s, 6H, H-7' and H-8'), 2.19 (m, 1H, H-3"), 2.90 (d, 2H, 6.9 Hz, H-2"), 5.60 (d, 1H, 10.0 Hz, H-5'), 5.99 (s, 1H, H-3), 6.90 (d, 1H, 10.0 Hz, H-4'), 7.30 (m, 1H, phenyl), 7.40 (m, 4H, phenyl), 14.73 (s, 1H, 5-OH); ${ }^{13} \mathrm{C} \mathrm{NMR} \mathrm{(75} \mathrm{MHz,}$ $\left.\mathrm{CDCl}_{3}\right) \delta 159.6(\mathrm{C}-2), 112.6(\mathrm{C}-3), 154.7(\mathrm{C}-4), 102.2(\mathrm{C}-$ 4a), 164.5 (C-5), 106.9 (C-6), 156.4 (C-7), 101.4 (C-8), 157.8 (C-8a), 115.5 (C-4'), 126.2 (C-5'), 79.8 (C-6'), 28.1 (C-7'), 28.1 (C-8'), 206.7 (C-1'), 53.5 .5 (C-2”), 25.0 (C3"), 22.6 (C-4"), 22.6 (C-5"), 139.2 (C-1"”), 127.1 (C2"' and C-6""), 127.5 (C-3"' and C-5"'), 128.1 (C-4"").

Compound 9. $\mathrm{C}_{22} \mathrm{H}_{26} \mathrm{O}_{5}$, 5-hydroxy-6-(2-methyl-1oxobutyl)-4-n-propyl-6',6'-dimethylpyrano(2',3':7,8)coumarin. Yellow oil; ${ }^{1} \mathrm{H} \mathrm{NMR}\left(300 \mathrm{MHz}, \mathrm{CDCl}_{3}\right) \delta 0.89$ (t, 3H, 7.5 Hz, H-4"), 0.97 (t, 3H, 7.3 Hz, H-3"'), 1.17 (d, 3H, 6.7 Hz, H-5"), 1.40 (m, 2H, H-3"), 1.51 (s, 6H, H7' and H-8'), 1.56 (m, 2H, H-2'”'), 2.89 (t, 2H, $7.5 \mathrm{~Hz}, \mathrm{H}-$ 1"”), 3.72 (m, 1H, H-2"), 5.56 (d, 1H, 10.0 Hz, H-5'), 6.79 (d, 1H, 10.0 Hz, H-4'), 5.90 (s, 1H, H-3), 15.29 (s, $1 \mathrm{H}, 5-\mathrm{OH}) .{ }^{13} \mathrm{C}$ NMR $\left(75 \mathrm{MHz}, \mathrm{CDCl}_{3}\right) \delta 159.6(\mathrm{C}-2)$, 110.1 (C-3), 159.2 (C-4), 103.1 (C-4a), 165.1 (C-5), 106.7 (C-6), 157.1 (C-7), 101.4 (C-8), 154.9 (C-8a), 115.5 (C4'), 126.1 (C-5'), 79.5 (C-6'), 27.9 (C-7'), 27.9 (C-8'), 211.7 (C-1"), 46.5 (C-2"), 26.6 (C-3"), 11.7 (C-4”), 16.6 (C-5”), 38.3 (C-1"”), 22.6 (C-2"”), 13.8 (C-3'); EIMS m/ z $370[\mathrm{M}]^{+}(35 \%), 355$ (100), 337 (33), 313 (23); $\mathrm{v}_{\max }$ I $\mathrm{cm}^{-1}$ 3489, 1748, 1614, 1581, 1189, 1146, 1113 (film $\left.\mathrm{CHCl}_{3}\right) ; \lambda_{\text {max }} / \mathrm{nm}\left(\mathrm{CH}_{3} \mathrm{OH}\right) 227,287,337 ; \lambda_{\max } \mathrm{NaOH} / \mathrm{nm}$ 247, 312, 413.

\section{Results and Discussion}

From the hexane extract of the stems of $K$. lathrophyton we isolated two new prenylated xanthones, $\mathbf{1}$ and $\mathbf{2}$, and two new 4-s-butylcoumarins, $\mathbf{4}$ and $\mathbf{5}$, along with the known 2,3-methylenedioxyxanthone $3^{13}$, 7-hydroxy-8-(2-methyl1-oxobutyl)-4-n-propyl-6',6'-dimethylpyrano (2',3':5,6)- 
<smiles>[R2]c1cc([R1])c2oc3cc4c(c(O)c3c(=O)c2c1)C=CC(C)(CCC=C(C)[18F])O4</smiles><smiles>O=c1c2ccccc2oc2cc3c(cc12)OCO3</smiles><smiles>[R]c1c(O)c2ccc(=O)oc2c2c([R])cc(=O)oc12</smiles><smiles>[R]c1c2c(c3oc(=O)cc([R])c3c1O)C=CC(C)(C)O2</smiles><smiles>[R]=[R]=[W]</smiles>

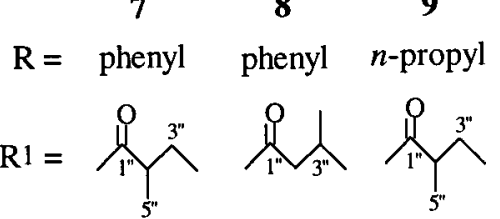<smiles>CC(C)=CCC/C(C)=C/CC/C(C)=C/CCC1(C)CCc2cc(O)cc(C)c2O1</smiles>

10

coumarin $6^{14}, 5$-hydroxy-6-(2-methyl-1-oxobutyl)-4phenyl-6',6'-dimethylpyrano (2',3':7,8)-coumarin $7^{14,15}$, 5-hydroxy-6-(3-methyl-1-oxobutyl)-4-phenyl-6',6'dimethylpyrano( $\left.2^{\prime}, 3^{\prime}: 7,8\right)$-coumarin $\mathbf{8}^{10,14-16}, 5$-hydroxy-6( 2-methyl-1-oxobuty 1)-4-n-propy 1-6', 6' dimethylpyrano( $\left.2^{\prime}, 3^{\prime}: 7,8\right)$-coumarin $9^{14}$, d-tocotrienol $\mathbf{1 0}^{17}$, friedelin ${ }^{18}$, 24a-ethylcholest-5-en-3-one, and , 24aethylcholest-5,22-dien-3-ol ${ }^{19}$. Compound 6 was previously reported as a synthetic product ${ }^{14}$. The molecular formulae of these compounds were determined by EI mass spectrometry and by ${ }^{1} \mathrm{H}$ and ${ }^{13} \mathrm{C}$ NMR.

Xanthone 1, yellow crystals, mp $142-143^{\circ} \mathrm{C}$, has the molecular formula $\mathrm{C}_{23} \mathrm{H}_{22} \mathrm{O}_{5}$. The UV spectrum showed absorptions at 238, 268, 294, and $312 \mathrm{~nm}$, and its IR spectrum showed absorptions at 3338, 1652, 1613, and $1581 \mathrm{~cm}^{-1}$, suggesting the xanthone skeleton with a chelated hydroxyl group ${ }^{6,21}$. Both the ${ }^{1} \mathrm{H}$ and ${ }^{13} \mathrm{CNMR}$ spectra (Table 1) revealed the presence of a prenyl moiety characterized by the signals at $\delta 5.09$ (bt, 6.9 Hz, H-10'), 1.57 (s, H-13'), 1.66 (s, H-12'), 132.0 (C-11'), 123.6 (C-10'), 17.6 (C-13'), 25.7 (C-12'), and 22.6 (C-9'). The presence of a chromene ring system was indicated by an AX proton system at $\delta 5.56(\mathrm{~d}, 10.0 \mathrm{~Hz}, \mathrm{H}-5$ ') and $6.76\left(\mathrm{~d}, 10.0 \mathrm{~Hz}, \mathrm{H}-4^{\prime}\right)$ and by the signals at $126.5\left(\mathrm{C}-5^{\prime}\right)$, 115.8 (C-4'), 81.0 (C-6'), and 27.7 (C-7'). The lack of one methyl group signal, that would be necessary for the 6, 6 'dimethylchromene system and the appearance of one addtional methylene signal at $\delta 41.7\left(\mathrm{C}-8^{\prime}\right)$, suggested that one methyl group was substituted by a 4-methylpent-3-enyl group. This fact was corroborated by the appearance of an abundant fragment ion at $m / z 295\left([\mathrm{M}]^{+}-83\right.$ ) resulting from the loss of the 4-methyl-3-pentenyl moiety. The analysis of an aromatic ABC type proton system at $\delta 7.24(\mathrm{t}, 8.0 \mathrm{~Hz}, \mathrm{H}-7), 7.32$ (dd, 8.0, $1.7 \mathrm{~Hz}, \mathrm{H}-6)$, and $7.75(\mathrm{dd}, 8.0,1.7 \mathrm{~Hz}, \mathrm{H}-8)$, suggested the presence of three adjacent protons. A shielded isolated proton at $\delta 6.36(\mathrm{~s}, \mathrm{H}-4)$ was in agreement with a pentasubstituted aromatic A ring. The presence of a conjugated carbonyl and a chelated hydroxyl were confirmed by the signals at $\delta 180.7$ (C9) and $13.16(\mathrm{~s}, 1-\mathrm{OH})$, respectively. The long range correlations (Table 2) of the signal at $\delta 13.16$ (s, $1-\mathrm{OH})$ with the signals at $\delta 157.8$ (C-1), 104.8 (C-2), and 103.8 (C-9a), jointly with the correlations of the signal at $\delta 6.36(\mathrm{H}-4)$ with $\delta 161.3(\mathrm{C}-3)$, $156.3(\mathrm{C}-4 \mathrm{a})$ and $104.8(\mathrm{C}-2)$ and that of $\delta 5.56\left(\mathrm{H}-5^{\prime}\right)$ with $\delta$ 
104.8 (C-2) allowed an unequivocal assignment of the A ring in the xanthone moiety. In the B ring, the deshielded signal of H- 8 at $\delta 7.75$ indicated a periplanar relation with the carbonyl. The long range correlations of $\mathrm{H}-8$ with the signals at $\delta 144.2$ (C-5a) and 121.1 (C-8a) and those of the signal at $\delta 7.24(\mathrm{H}-7)$ with $\delta 144.3$ (C-5), established the hydroxyl position at C-5. The unequivocal assignments of carbons C-6, C-7, and C-8 were made by a ${ }^{1} \mathrm{H}-{ }^{13} \mathrm{C} C O S Y(J=140 \mathrm{~Hz})$ experiment.

Xanthone $\mathbf{2}$ had the same molecular formula as xanthone 1, $\mathrm{C}_{23} \mathrm{H}_{22} \mathrm{O}_{5}$, and showed similar UV, IR, and MS data. Nevertheless their ${ }^{1} \mathrm{H}$ NMR spectra (Table 1), showed significant differences in the aromatic region. The presence of a 1,2,4 ABC type proton system in $\mathbf{2}$ was deduced by the signals at $\delta 7.25$ (dd, 9.0; 3.0 Hz, H-6), 7.33 (d, $9.0 \mathrm{~Hz}, \mathrm{H}-5$ ), and 7.59 (d, 3.0 $\mathrm{Hz}, \mathrm{H}-8$ ). The long range correlations (Table 2) allowed an unequivocal assignment of the $\mathrm{B}$ ring and confirmed the structure proposed.

The 2,3-methylenedioxyxanthone $\mathbf{3}$ has been already isolated from Hypericum mysorense Heyne ${ }^{13}$, but because of some divergences in the ${ }^{13} \mathrm{C}$ NMR data attribution, we made a reassignment. In the ${ }^{1} \mathrm{H}$ NMR spectrum (Table 1 ), the presence of two singlets at $\delta 6.89(\mathrm{H}-4)$ and $7.64(\mathrm{H}-1)$, and other four aromatic proton signals at $\delta 7.44,(\mathrm{~d}, 8.0 \mathrm{~Hz}$, H-5), 7.68 (td, 1.5; 8.0 Hz, H-6), 7.36 (t, $8.0 \mathrm{~Hz}, \mathrm{H}-7$ ), and $8.31(\mathrm{dd}, 1.5 ; 8.0 \mathrm{~Hz}, \mathrm{H}-8)$ established a disubstituted xanthone with a methylenedioxy group, $\delta 6.12(s, \mathrm{H}-10)$, at 2,3 positions.

Table 1. ${ }^{1} \mathrm{H}(300 \mathrm{MHz})$ and ${ }^{13} \mathrm{C}$ NMR $(75 \mathrm{MHz})$ data for compounds $\mathbf{1}, \mathbf{2}$ and $\mathbf{3}\left(\mathrm{CDCl}_{3}, \delta\right.$ in ppm).

\begin{tabular}{|c|c|c|c|c|c|c|}
\hline & \multicolumn{2}{|c|}{1} & \multicolumn{2}{|l|}{2} & \multicolumn{2}{|l|}{3} \\
\hline $\mathrm{H} / \mathrm{C}$ & ${ }^{1} \mathrm{H}$ & ${ }^{13} \mathrm{C}$ & ${ }^{1} \mathrm{H}$ & ${ }^{13} \mathrm{C}$ & ${ }^{1} \mathrm{H}$ & ${ }^{13} \mathrm{C}$ \\
\hline 1 & & 157.8 & & 157.5 & $7.64,1 \mathrm{H}, \mathrm{s}$ & 103.4 \\
\hline 2 & & 104.8 & & 103.4 & & 145.3 \\
\hline 3 & & 161.3 & & 161.2 & & $153.6 *$ \\
\hline 4 & $6.36,1 \mathrm{H}, \mathrm{s}$ & 94.7 & $6.31,1 \mathrm{H}, \mathrm{s}$ & 94.6 & $6.89,1 \mathrm{H}, \mathrm{s}$ & 97.9 \\
\hline $4 a$ & & 156.3 & & 157.3 & & $153.7 *$ \\
\hline 5 & & 144.3 & $7.33,1 \mathrm{H}, \mathrm{d}(9.0 \mathrm{~Hz})$ & 118.9 & $7.44,1 \mathrm{H}, \quad \mathrm{d}(8.0 \mathrm{~Hz})$ & 117.6 \\
\hline $5 \mathrm{a}$ & & 144.2 & & 150.3 & & 156.0 \\
\hline 6 & $7.32,1 \mathrm{H}, \mathrm{dd}(1.7 ; 8.0 \mathrm{~Hz})$ & 120.2 & $7.25,1 \mathrm{H}, \mathrm{dd}(3.0 ; 9.0 \mathrm{~Hz})$ & 124.1 & $7.68,1 \mathrm{H}, \mathrm{td}(1.5 ; 8.0 \mathrm{~Hz})$ & 134.0 \\
\hline 7 & $7.24,1 \mathrm{H}, \mathrm{t}(8.0 \mathrm{~Hz})$ & 124.0 & & 152.8 & $7.36,1 \mathrm{H}, \mathrm{t}(8.0 \mathrm{~Hz})$ & 124.0 \\
\hline 8 & $7.75,1 \mathrm{H}, \mathrm{dd}(1.7 ; 8.0 \mathrm{~Hz})$ & 116.8 & $7.59,1 \mathrm{H}, \mathrm{d}(3.0 \mathrm{~Hz})$ & 109.0 & $8.31,1 \mathrm{H}, \mathrm{dd}(1.5 ; 8.0 \mathrm{~Hz})$ & 126.8 \\
\hline $8 \mathrm{a}$ & & 121.1 & & 120.9 & & 121.5 \\
\hline 9 & & 180.7 & & 180.5 & & 175.7 \\
\hline $9 \mathrm{a}$ & & 103.8 & & 104.2 & & 116.6 \\
\hline $\mathrm{O}_{2} \mathrm{CH}_{2}$ & & & & & $6.12, \mathrm{~s}$ & 102.4 \\
\hline 4, & $6.76,1 \mathrm{H}, \mathrm{d}(10.0 \mathrm{~Hz})$ & 115.8 & $6.77,1 \mathrm{H}, \mathrm{d}(10.0 \mathrm{~Hz})$ & 115.9 & & \\
\hline 5 ' & $5.56,1 \mathrm{H}, \mathrm{d}(10.0 \mathrm{~Hz})$ & 126.5 & $5.54,1 \mathrm{H}, \mathrm{d}(10.0 \mathrm{~Hz})$ & 126.3 & & \\
\hline $6^{\prime}$ & & 81.0 & & 80.8 & & \\
\hline $7^{\prime}$ & $1.46,3 \mathrm{H}, \mathrm{s}$ & 27.7 & $1.45,3 \mathrm{H}, \mathrm{s}$ & 27.2 & & \\
\hline $8^{\prime}$ & $1.78,2 \mathrm{H}, \mathrm{m}$ & 41.7 & $1.70,2 \mathrm{H}, \mathrm{m}$ & 41.7 & & \\
\hline $9^{\prime}$ & $2.10,2 \mathrm{H}, \mathrm{m}$ & 22.6 & $2.10,2 \mathrm{H}, \mathrm{m}$ & 22.6 & & \\
\hline $10^{\prime}$ & $5.09,1 \mathrm{H}, \mathrm{tl}(6.9 \mathrm{~Hz})$ & 123.6 & $5.10,1 \mathrm{H}, \operatorname{tl}(7.0 \mathrm{~Hz})$ & 123.7 & & \\
\hline $11^{\prime}$ & & 132.0 & & 131.9 & & \\
\hline $12^{\prime}$ & $1.66,3 \mathrm{H}, \mathrm{s}$ & 25.7 & $1.66,3 \mathrm{H}, \mathrm{s}$ & 25.6 & & \\
\hline 13 & $1.57,3 \mathrm{H}, \mathrm{s}$ & 17.6 & $1.58,3 \mathrm{H}, \mathrm{s}$ & 17.6 & & \\
\hline $1-\mathrm{OH}$ & $13.16,1 \mathrm{H}, \mathrm{s}$ & & $13.11,1 \mathrm{H}, \mathrm{s}$ & & & \\
\hline
\end{tabular}

*These signals may be interchanged; values in parentheses indicate coupling constants.

Table 2. ${ }^{1} \mathrm{H}^{13} \mathrm{C}$ COSY $(J 7.0$ and $9.0 \mathrm{~Hz})$ for compounds $\mathbf{1}, \mathbf{2}$ and $\mathbf{3}$.

\begin{tabular}{|c|c|c|c|c|c|}
\hline \multicolumn{2}{|r|}{1} & \multicolumn{2}{|c|}{2} & \multicolumn{2}{|c|}{3} \\
\hline${ }^{1} \mathrm{H}$ & ${ }^{1} \mathrm{H}-{ }^{13} \mathrm{C}$ & ${ }^{1} \mathrm{H}$ & ${ }^{1} \mathrm{H}-{ }^{13} \mathrm{C}$ & ${ }^{1} \mathrm{H}$ & ${ }^{1} \mathrm{H}-{ }^{13} \mathrm{C}$ \\
\hline $13.16(1-\mathrm{OH})$ & $\mathrm{C}-1 ; \mathrm{C}-2 ; \mathrm{C}-9 \mathrm{a}$ & $13.11(1-\mathrm{OH})$ & C-1; C-9a; C-2 & $7.64(\mathrm{H}-1)$ & $\mathrm{C}-4 \mathrm{a} ; \mathrm{C}-3$ \\
\hline $6.36(\mathrm{H}-4)$ & C-2; C-3; C-4a; C-9a & $6.31(\mathrm{H}-4)$ & $\mathrm{C}-4 \mathrm{a}$ & $6.89(\mathrm{H}-4)$ & $\mathrm{C}-9 \mathrm{a} ; \mathrm{C}-2$ \\
\hline $7.32(\mathrm{H}-6)$ & C- 8 & $7.33(\mathrm{H}-5)$ & C-7; C-8a & $7.44(\mathrm{H}-5)$ & \\
\hline $7.24(\mathrm{H}-7)$ & C-5; C-8a & $7.59(\mathrm{H}-8)$ & C-9; C-5a; C-6 & $7,68(\mathrm{H}-6)$ & \\
\hline $7.75(\mathrm{H}-8)$ & C-5a; C-6; C-8a; C-9 & & & $7.36(\mathrm{H}-7)$ & \\
\hline $6.76\left(\mathrm{H}-4^{\prime}\right)$ & C-1; C-3; C-6 & $6.77\left(\mathrm{H}-4^{\prime}\right)$ & & $8.31(\mathrm{H}-8)$ & \\
\hline $5.56\left(\mathrm{H}-5^{\prime}\right)$ & C-2; C-6 & $5.54\left(\mathrm{H}-5^{\prime}\right)$ & $\mathrm{C}-2 ; \mathrm{C}-6$ & & \\
\hline 1.45 (H-7') & C-5'; C-6'; C-8' & $1.45\left(\mathrm{H}-7^{\prime}\right)$ & $\mathrm{C}-5^{\prime} ; \mathrm{C}-6^{\prime}$ & & \\
\hline $2.10\left(\mathrm{H}-9^{\prime}\right)$ & & $2.10\left(\mathrm{H}-9^{\prime}\right)$ & & & \\
\hline 5.09 (H-10') & & $5.10\left(\mathrm{H}-10^{\prime}\right)$ & & & \\
\hline $1.57\left(\mathrm{H}-13^{\prime}\right)$ & $\mathrm{C}-11^{\prime} ; \mathrm{C}-12^{\prime}$ & $1.58\left(\mathrm{H}-13^{\prime}\right)$ & $\mathrm{C}-11^{\prime}$ & & \\
\hline $1.66\left(\mathrm{H}-12^{\prime}\right)$ & C-11'; C-13' & & & & \\
\hline
\end{tabular}


The ${ }^{13} \mathrm{C}$ NMR spectrum (Table 1) showed five deshielded signals at $\delta 175.7,156.0,153.7,153.6$ and 145.3 , that were assigned to carbons C-9, C-5a, C-4a, C-3 and C-2, respectively.

The ${ }^{1} \mathrm{H}_{-}{ }^{1} \mathrm{H}$ COSY and the long range correlations showed by the ${ }^{1} \mathrm{H}_{-}{ }^{13} \mathrm{C}$ COSY $\left(\begin{array}{ll}J & \mathrm{~Hz}\end{array}\right)$ (Table 2 ) confirmed the assignments for compound 3 . The correlations between the signal at $\delta 7.64(\mathrm{H}-1)$ with signals at $\delta 153.6(\mathrm{C}-3)$ and 153.7 $(\mathrm{C}-4 \mathrm{a})$ and those of the signal at $\delta 6.89(\mathrm{H}-4)$ with signals at $\delta$ 116.6 (C-9a) and 145.3 (C-2) substantiate the proposed structure.

Both compounds $\mathbf{4}$ and $\mathbf{5}$ have molecular formula $\mathrm{C}_{23} \mathrm{H}_{28} \mathrm{O}_{5}$, deduced by EIMS $\left(\mathrm{M}^{+}=384\right)$ and ${ }^{13} \mathrm{C}$ NMR. Spectral data suggested for both $\mathbf{4}$ and 5 the 4-alkylcoumarin skeleton with a chelated hydroxyl ${ }^{14,15}$. They showed very similar ${ }^{1} \mathrm{H}$ and ${ }^{13} \mathrm{C}$ NMR data and structurally differ only in the $\mathrm{C}-8$ acyl side chain. The ${ }^{1} \mathrm{H}$ NMR spectra (Table 3 ) of these compounds showed signals for the 6',6'-dimethylchromene ring, a H-3 singlet, one hydrogen of chelated hydroxyl, one acyl side chain and a 4-s-butyl group.

In compound 4, the 4-s-butyl group was characterized by the multiplet at $\delta 3.84,1 \mathrm{H}(\mathrm{H}-2$ '"'), a doublet at $\delta 1.24$, $3 \mathrm{H}$ (H-1"'), a multiplet at $\delta 1.77,2 \mathrm{H}$ (H-3"') and a triplet at $\delta 0.97,3 \mathrm{H}\left(\mathrm{H}-4\right.$ "'), in the ${ }^{1} \mathrm{H}$ NMR spectrum, and by the signals at $\delta 37.5$ (CH, C-2"'”), $20.0\left(\mathrm{CH}_{3}, \mathrm{C}-1\right.$ '”'), 29.5 $\left(\mathrm{CH}_{2}, \mathrm{C}-3\right.$ "' $)$ and $11.8\left(\mathrm{CH}_{3}, \mathrm{C}-4\right.$ "' $)$ in the ${ }^{13} \mathrm{C} \mathrm{NMR}$ spectrum, while the 3-methyl-1-oxobutyl side chain was characterized in the ${ }^{1} \mathrm{H}$ NMR spectrum by a doublet at $\delta$ $3.15,2 \mathrm{H}$ (H-2"), a multiplet at $\delta 2.30,1 \mathrm{H}$ (H-3"), a doublet at $\delta 1.02,6 \mathrm{H}(\mathrm{H}-4$ " and $\mathrm{H}-5 ")$ and in the ${ }^{13} \mathrm{C}$ NMR spectrum by the signals at $\delta 206.3\left(\mathrm{C}=\mathrm{O}, \mathrm{C}-1\right.$ '”), $53.6\left(\mathrm{CH}_{2}\right.$, $\mathrm{C}-2$ "), $25.6(\mathrm{CH}, \mathrm{C}-3$ ") and the methyl groups at $\delta 22.6$ (C-4" and C-5").

The locations of the substituents around the aromatic coumarin ring are supported by long range correlations (Table 4) and nOe experiments. The long range correlations of the signal at $\delta 6.13(\mathrm{H}-3)$ with the resonances at $\delta 102.8$ and 159.6 permitted assignment of these signals to $\mathrm{C}-4 \mathrm{a}$ and $\mathrm{C}-2$, respectively. In accordance with the accepted neoflavonoid oxidation pattern ${ }^{14,}{ }^{20}$, carbons C-5 and C-7 of the aromatic ring are oxygenated, thus the correlations of the hydrogen at $\delta 14.49$ with the resonances at $\delta 104.7$ (C8), 106.2 (C-6), and 162.9 (C-7) and the correlation of the signal at $\delta 6.74\left(\mathrm{H}-4{ }^{\prime}\right)$ with the signal at $\delta 157.3(\mathrm{C}-5)$ allowed location of the $\mathrm{OH}$ at $\mathrm{C}-7$ and the 6',6'-dimethylchromene ring at C-5 and C-6. Consequently the 3-methyl-1-oxobutyl group was placed at $\mathrm{C}-8$. By exclusion, the $s$-butyl group was located at $\mathrm{C}-4$. This assumption was corroborated by the enhancement of the signal at $\delta 1.24(\mathrm{H}-1$ "') in the NOEDIF experiment when H-3 ( $\delta$ 6.13) was irradiated.

The analysis of the ${ }^{1} \mathrm{H}$ NMR spectrum of compound 5 was more complicated due the overlap of three pairs of hydrogen signals of the s-butyl and 2-methyl-1-oxo-butyl groups. However, these signals were unambiguously assigned with the help of the one bond ${ }^{1} \mathrm{H}-{ }^{13} \mathrm{C} \mathrm{COSY}$ spectrum (Table 3). This spectrum showed correlations of

Table 3. ${ }^{1} \mathrm{H}(300 \mathrm{MHz})$ and ${ }^{13} \mathrm{C}(75 \mathrm{MHz}) \mathrm{NMR}$ data for compounds 4 and $\mathbf{5}\left(\mathrm{CDCl}_{3}, \delta\right.$ in ppm).

\begin{tabular}{|c|c|c|c|c|}
\hline \multirow[b]{2}{*}{$\mathrm{H} / \mathrm{C}$} & \multicolumn{2}{|c|}{4} & \multicolumn{2}{|c|}{5} \\
\hline & ${ }^{1} \mathrm{H}$ & ${ }^{13} \mathrm{C}$ & ${ }^{1} \mathrm{H}$ & ${ }^{13} \mathrm{C}$ \\
\hline 2 & & 159.6 & & 159.6 \\
\hline 3 & $6.13,1 \mathrm{H}, \mathrm{s}$ & 107.6 & $6.13,1 \mathrm{H}, \mathrm{s}$ & 107.6 \\
\hline 4 & & 164.1 & & 164.2 \\
\hline $4 a$ & & 102.8 & & 102.8 \\
\hline 5 & & 157.3 & & 156.5 \\
\hline 6 & & 106.2 & & 106.3 \\
\hline 7 & & 162.9 & & 162.9 \\
\hline 8 & & 104.7 & & 104.3 \\
\hline $8 \mathrm{a}$ & & 156.6 & & 157.1 \\
\hline $4^{\prime}$ & $6.74,1 \mathrm{H}, \mathrm{d}(10.0 \mathrm{~Hz})$ & 116.1 & $6.73,1 \mathrm{H}, \mathrm{d}(10.0 \mathrm{~Hz})$ & 116.1 \\
\hline 5 , & $5.59,1 \mathrm{H}, \mathrm{d}(10.0 \mathrm{~Hz})$ & 126.3 & $5.58,1 \mathrm{H}, \mathrm{d}(10.0 \mathrm{~Hz})$ & 126.3 \\
\hline 6 & & 79.7 & & 79.6 \\
\hline 7 & $1.54,3 \mathrm{H}, \mathrm{s}$ & 28.2 & $1.53,3 \mathrm{H}, \mathrm{s}$ & 28.1 \\
\hline 8 & $1.54,3 \mathrm{H} . \mathrm{s}$ & 28.2 & $1.52,3 \mathrm{H}, \mathrm{s}$ & 28.2 \\
\hline 1, & & 206.3 & & 210.8 \\
\hline 2, & $3.15,2 \mathrm{H}, \mathrm{d}(6.7 \mathrm{~Hz})$ & 53.6 & $3.89,1 \mathrm{H}, \mathrm{m}$ & 46.9 \\
\hline $3^{\prime \prime}$ & $2.30,1 \mathrm{H}, \mathrm{m}$ & 25.6 & $1.40,2 \mathrm{H}, \mathrm{m}$ & 27.2 \\
\hline 4, & $1.02,3 \mathrm{H}, \mathrm{d}(6.7 \mathrm{~Hz})$ & 22.6 & $0.97,3 \mathrm{H}, \mathrm{t}(7.5 \mathrm{~Hz})$ & 11.8 \\
\hline 5, & $1.02,3 \mathrm{H}, \mathrm{d}(6.7 \mathrm{~Hz})$ & 22.6 & $1.25,3 \mathrm{H}, \mathrm{d}(6.6 \mathrm{~Hz})$ & 16.6 \\
\hline $1,$, & $1.24,3 \mathrm{H}, \mathrm{d}(6.7 \mathrm{~Hz})$ & 20.0 & $1.25,3 \mathrm{H}, \mathrm{d}(6.6 \mathrm{~Hz})$ & 20.0 \\
\hline $2,$, & $3.84,1 \mathrm{H}, \mathrm{m}$ & 37.5 & $3.89,1 \mathrm{H}, \mathrm{m}$ & 37.5 \\
\hline $3,$, & $1.77,2 \mathrm{H}, \mathrm{m}$ & 29.5 & $1.69,2 \mathrm{H}, \mathrm{m}$ & 29.5 \\
\hline $4,$, & $0.97,3 \mathrm{H}, \mathrm{t}(7.3 \mathrm{~Hz})$ & 11.8 & $0.97,3 \mathrm{H}, \mathrm{t}(7.5 \mathrm{~Hz})$ & 11.7 \\
\hline 7-OH & $14.49,1 \mathrm{H}, \mathrm{s}$ & & $14.39,1 \mathrm{H}, \mathrm{s}$ & \\
\hline
\end{tabular}

Values in parentheses indicate coupling constants. 
Table 4. ${ }^{1} \mathrm{H}-{ }^{13} \mathrm{C} \operatorname{COSY}(J=7.0$ and $9.0 \mathrm{~Hz})$ for compounds 4 and 5 .

\begin{tabular}{|c|c|}
\hline$\delta(\mathrm{H})$ & $\delta(\mathrm{C})$ \\
\hline \multicolumn{2}{|l|}{ Compound 4} \\
\hline $3.15(2 \%)$ & $206.3(1 ’)$ \\
\hline $6.74\left(4^{\prime}\right)$ & $157.3(5)$ \\
\hline $6.13(3)$ & $102.8(4 a) ; 159.6(2)$ \\
\hline $14.49(7-\mathrm{OH})$ & $104.7(8) ; 106.2(6) ; 162.9(7)$ \\
\hline \multicolumn{2}{|l|}{ Compound $\mathbf{5}$} \\
\hline 1.25 (5" and 4"') & 46.9 (2"); $210.8(1$ (1); $29.5(2$ (2)); 164.2 (4) \\
\hline $6.73\left(4^{\prime}\right)$ & $156.5(5) ; 106.3(6)$ \\
\hline $6.13(3)$ & $102.8(4 a) ; 159.6(2)$ \\
\hline $14.39(7-\mathrm{OH})$ & $104.3(8) ; 106.3(6) ; 162.9(7)$ \\
\hline
\end{tabular}

the multiplet at $\delta 3.89,2 \mathrm{H}$, with the signals at $\delta 46.9$ (C2 ") and 37.5 (C-2"'), of the triplet at $\delta 0.97,6 \mathrm{H}$, with the signals at $\delta 11.8$ (C-4") and 11.7 (C-4" ") and of the doublet at $\delta 1.25,6 \mathrm{H}$, with the signals at $\delta 16.6(\mathrm{C}-5 ")$ and 20.0 (C-1"”). The signals at $\delta 46.9(\mathrm{CH}), 16.6\left(\mathrm{CH}_{3}\right), 11.8$ $\left(\mathrm{CH}_{3}\right), 210.8(\mathrm{C}=\mathrm{O})$ and $27.2\left(\mathrm{CH}_{2}\right)$ were assigned to the 2-methyl-1-oxobutyl group, while the signals at $\delta 37.5$ $(\mathrm{CH}), 20.0\left(\mathrm{CH}_{3}\right), 11.7\left(\mathrm{CH}_{3}\right)$ and $29.5\left(\mathrm{CH}_{2}\right)$ were assigned to the s-butyl group. The analysis of the long range correlations spectrum (Table 4) facilitated the location of a hydroxyl group at C-7, of the 2,2-dimetylchromene ring at C-5 and C-6 and of the 2-methyl-1-oxobutyl group at C-8. The s-butyl group was located at C-4 due the observed long range correlation between the signal at $\delta 1.25(\mathrm{H}-$ 1 "') and the signal at $\delta 164.2(\mathrm{C}-4)$ and by the enhancement of the signal at $\delta 1.25$ (H-1"') in the NOEDIF experiment when H-3 ( $\delta$ 6.13) was irradiated.

The structures of the known compounds $6,7,8$, and 9 were determined by a combination of IV, UV, EM, ${ }^{1} \mathrm{H}$ and ${ }^{13} \mathrm{C}$ NMR, DEPT, ${ }^{1} \mathrm{H}-{ }^{1} \mathrm{H} \mathrm{COSY}$ and ${ }^{1} \mathrm{H}-{ }^{13} \mathrm{C} \mathrm{COSY}$ (one bond and multiple bonds) data. This is the first time that their ${ }^{13} \mathrm{C}$ NMR signals assignments are reported (Experimental section).

\section{Acknowledgments}

The authors are grateful to João Lago (IQ-USP) for recording the $\alpha_{\mathrm{D}}$ values, to Roy Funch from Fundação Chapada Diamantina (Lençois) for providing local support during the plant collect, as well as to CAPES for the MSc fellowships to JTSN. This work was supported by grants from $\mathrm{CNPq}$ and FINEP.

\section{References}

1. Sultanbawa, M. U. S. Tetrahedron 1980, 36, 1465.

2. Gottlieb, O. R.; Magalhães, M. T.; Camey, M.; Mesquita, A. A. L.; Corrêa, D. B. Tetrahedron 1966, 22, 1777.

3. Gottlieb, O. R.; Magalhães, M. T.; da Silva Pereira, M. O.; Mesquita, A. A. L.; de Barros Corrêa, D.; Oliveira, G. G. Tetrahedron 1968, 24, 1601.

4. Gottlieb, O. R.; Mesquita, A. A. L.; Da Silva, E. M.; Melo, M. T. Phytochemistry 1969, 8, 665.

5. Gottlieb, O. R.; Stefani, G. M. Phytochemistry 1970, $9,453$.

6. de Barros Corrêa, D.; Fonseca e Silva, L. G.; Gottlieb, O. R.; Gonçalves, S. J. Phytochemistry 1970, 9, 447.

7. Gottlieb, O. R.; Mesquita, A. A. L.; de Oliveira, G. G.; de Melo, M. T. Phytochemistry 1970, 9, 2537.

8. Gottlieb.O. R.; Nagem, T. J. Rev. Latinoam. Quim., 1977, 8, 137.

9. Lopes, J. L. C.; Lopes, J. N. C.; Gilbert, B.; Bonini, S. E. Phytochemistry 1977, 16, 1101.

10. Nagem, T. J.;De A. e Silva, M. Phytochemistry 1988, 27, 2961.

11. Cruz, F. G.; Moreira, L. M.; David, J. M.; Guedes. M. L. S.; Chávez, J. P. Phytochemistry 1998, 47, 1363.

12. Cruz, F. G.; Santos, N. A. S.; David, J. M.; Guedes. M. L. S.; Chávez, J. P. Phytochemistry 1998, 48, 703.

13. Balachandran, S.; Vishwakarma, R. A.; Popli, S. P. Indian J. Chem., 1988, 27B, 385.

14. Carpenter, I.; McGarry, E. J.; Scheinmann, F. J. Chem. Soc.(C) 1971, 3783.

15. Bandaranayake, W. M.; Selliah, S. S.; Sultanbawa, M. U. S. Phytochemistry 1975, 14, 265.

16. Chakraborty, D. P.; Chatterji, D. J. Org. Chem. 1969, 34, 3784.

17. Monache, F. D.; Marta, M.; Mac-Quhae, M. M.; Nicoletti, M. Gaz. Chim. Ital. 1984, 114, 135.

18. Patra, A.; Mukhopadhyay, A. K.; Mitra, A. K.; Org. Mag. Reson. 1981, 17, 166.

19. Wright, J. L. C.; McInnes, A. G.; Shimizu, S.; Smith, D. G.; Walter, J. A.; Idler, D.; Khalil, W. Can. J. Chem. 1978, 56, 1898.

20. Ollis, W. D. An. Acad. brasil. Ciênc. 1970, 42, Supl., 9.

21. Pimenta, A.; Mesquita, A. A. L.; Camey, M.; Gottlieb, O. R.; Magalhães, M. T. An. Acad. brasil. Ciênc. 1964,36, 39.

Received: February 11, 2000

Published on the web: November 29, 2000 